JURNAL SOSIAL-EKONOMI PERTANIAN DAN AGRIBISNIS

JOURNAL ON SOCIO-ECONOMICS OF AGRICULTURE AND AGRIBUSINESS

\title{
IRIGASI TETES DI LAHAN KERING UNTUK KETAHANA PANGAN DAN PENGHIDUPAN PETANI YANG LEBIH BAIK (Analisis Perubahan Teknologi pada Budidaya Beberapa Jenis Tanaman di Pusat Unggulan Lahan Kering Kepulauan Undana)
}

\author{
I Wayan Nampa ${ }^{1,2 \& 3}$ Salmijati Kaunang ${ }^{1 \& 2}$ Made Tusan Surayasa ${ }^{1}$ \\ 1) Program Studi Agribisnis Fakultas Pertanian Undana, Kota Kupang, Nusa Tenggara \\ Timur \\ 2) Pusat Unggulan Lahan Kering Kepulauan Universitas Nua Cendana, Kota Kupang, Nusa \\ Tenggara Timur \\ 3)Email: wayannampa@staf.undana.ac.id, salmijati.kaunang@gmail.com, \\ 2son.pande@gmail.com \\ HP. $08113828669,08221038872,08123799858$
}

\begin{abstract}
ABSTRAK
Nusa Tenggara Timur memiliki potensi lahan kering mencapai 3.216.173 ha. Potensi tersebut belum banyak berkontribusi terhadap ketahanan pangan dan juga peningkatan pendapatan petani. Air merupakan faktor pembatas utama dalam usaha mengoftimalkan pertanian di lahan kering. Irigasi tetes merupakan teknologi pengairan yang telah banyak berkembang namun belum dimanfaatkan pada PErtanian lahan Kering di NTT. Diperlukan kajian finasial mengenai kelayakan teknologi tersebut. Penelitian dilakukan di lahan UPT Laboratorium Lapangan Terpadu/PUI Lahan Kering Kepulauan Universitas Nusa Cendana, dengan beberapa analisis finansial. Hasil penelitian menunjukkan bahwa rata-rata pendapatan (are) dari berbagai jenis komoditas yang diusahakan adalah Rp. 944,278.24 per are atau Rp. 94.427.824,- per hektar. Secara finansial, teknologi irigasi tetes pada Agribisnis mampu memberikan keuntungan pada tingkat suku bunga 12\%. Hal ini menunjukkan bahwa, penggunakan teknologi prospektif, dan tetap dapat memberikan keutungan pada inflasi $12 \%$ per tahun. Introduksi teknologi irigasi tetes mampu memberikan keutungan diatas suku bunga rata-rata. Sehingga secara finansial introduksi teknologi irigasi tetes layak dan menguntungkan. Selain itu, Irigasi tetes memberikan peluang produksi sepanjang tahun sedangkan metoda konvensional hanya satu kali tanam dalam satu tahun. Hasil produksi yang berkelanjutan juga mendapat insentif harga yang lebih baik karena kurangnya penawaran (supply) karena karena sebagian besar petani masih berproduksi secara konvensional.
\end{abstract}

Kata Kunci: lahan kering, irigasi tetes, kelayakan finansial 


\title{
DRIP IRIGATION FOR SUSTAINABLE LIFELIHOOD ON DRY-LAND AGRICULTURE (Finansial Analysis on Changing Wather Management Tecnology at the Dry- land Agricultural Production Activities)
}

\begin{abstract}
East Nua Tengara have's 3.216.173 hectars dry land potencial for agricultural. Actualy, the land contribution on agricultural production still minimum. Necessary improve technology for increasing land contribution. water is the main factor in the production process other than land and the dry-land, wates is limited availability in Dry-land. Drip irrigation is one of technology to propuses innovation for strengthen capastity and kontinous production in agriculture. This reseach has ben conducted on 2017 at the UPT Laboratorium Pangan Terpadu/PUI Lahan Kering Kepulauan UNDANA. This reseach analysis of change technology veasibility by financial analysis. The result of reseach show's is the income per are farm activity folowing drip irrigation technology is Rp. 944,278.24 per are (Rp. 94.427.824,- per hectar). From the finansial analysis show farm activity folowing drip irrigation technology is visible and proper for provit on $12 \%$ discount rate. Drip irrigation technology develop opportunities to continouing production, and the other hand convensional production only one seasion on one year.
\end{abstract}

Keyword: dry-land, drip irrigation, agriculture, veasibility study, financial annalysis.

\section{PENDAHULUAN}

Lahan kering merupakan salah satu potensi pertaian yang dapat dikembangkan untuk memenuhi kebutuhan berbagai kebutuhan pangan manusia. Namun, sampai saat ini lahan kering belum dimanfaatkan secara serius. Data BPS(2017)menyebutkan luas Lahan Kering di seluruh Indonesia mencapai 63.466.495 ha, namun belum dimanfaatkan. Provinsis Nusa Tenggara Timur (NTT) memiliki lahan kering sekitar 3.216.173 ha, namun belum mampu dimanfaatkan secara oftimal. NTT merupakan provinsi kepulauan dingan karakteristik iklim semi arid (Benu \& Mudita, 2013). Kondisi iklim seperti ini memiliki keterbatasan dalam berproduksi karena ketersediaan air yang juga terbatas (Benu, 2013b).Pada sisi yang lain, lahan pertanian semakin terbatas sehingga tidak ada pilihan bahwa lahan kering akan menjadi tumpuan dalam pemenuhan berbagai kebutuhan manusia di masa depan.

NTT mempunyai potensi lahan kering yang luas, namun belum dapat memnuhi kebutuhan pangan regionalnya. Padahal apabila dilihat dari rasio ketersediaan lahan dengan jumlah penduduk masih relatif besar. Penelitian Likadja (2016) dan Mamami (2004) menyebutkan bahwa hampir semua kabupaten di NTT mengalami kekurangan ketersediaan pangan setiap tahun karena lama ketersediaan pangan ekuivalen beras dalam 10 tahun terakhir selalu kurang dari 360 hari, kecuali Kabupaten Manggarai, Rote Ndao dan Sumba Tengah. Ketidakcukupan pangan ini tidak terlepas dari kondisi NTT yang memiliki iklim semi ringkai (semi arid), dimana rasio rerata presipitasi tahunan yang meliputi curah hujan dan embun terhadap potensi evapotransporasi tahunan lebih kecil dari 0,65 (Mudita, 2013b). 
Kondisi ini mempengaruhi dan menyebabkan luas tanam, intensitas penanaman dan produktivitas lahan pertanian menjadi rendah. Rendahnya produktifitas pertanian juga tidak terlepas dari orietasi petani dalam menjalankan uaha taninya. Petani NTT masih menjalankan pola pertanian subsisten khususnya Timor Barat dan Sumba yang masih berorientasi pada pemenuhan pangan keluarga dan hanya sebagian kecil hasil usahanya masuk pasar (Benu, 2013b). Padahal pada sisi yang lain kebutuhan rumah tangga semakin kompleks seiring perkembangan jaman.

Ketersediaan pangan dalam jumlah yang cukup dengan mutu yang baik, aman dan merata di semua rumah tangga, maka produksi pangan harus ditingkatkan, distribusi pangan harus merata dan dapat menjangkau seluruh wilayah, pangan harus dapat diakses semua penduduk dan pengolahan pangan harus memenuhi kaidah gizi dan kesehatannya.

Masalahnya adalah bagaimana meningkatkan produksi pangan untuk mencapai kecukupan pangan secara merata di seluruh wilayah dan juga meningkatkan pendapatan dan kesejahteraan petani. Teknologi adalah salah satu pilihan tepat dalam mengisi gap antara kebutuhan dan kecukupan pangan dan peningkatan produktivitas pertanian ditengah keterbatasan daya dukung lahan dan air. Benu (2013a) mengungkapkan pertanian di daerah ringkai dan semiringkai memiliki keterbatasan air, sehingga harus dilakukan konservasi air hujan dan pengelolaan ketersediaan pasokan air irigasi yang efisien. Introduksi teknologi ini membutuhkan investasi tambahan sehingga penerapannya secara luas harus dilakukan melalui kajian inovasi pengelolaan irigasi air. Karena apabila teknologi tersebut dapat diterapkan, petani akan dapat menerima dan pengaplikasikannya. Hasil penelitian Nampa dkk (2017) pada tiga kelompok tani menunjukkan bahwa petani dapat menerapkan teknologi budidaya dengan baik pada lahan bekas pertambangan mangan menjadi lahan pertanian yang produktif dan dapat menjadi tumpuan perekonomian keluarga anggota kelompok tani. Namun demikian, nyatanya petani belum mampu atau mau mengadopsi teknologi irigasi tetes dalam proses budidaya.

Penelitian ini dilakukan untuk mengetahui tingkat kelayakan finansial dari penerapan teknologi irigasi tetes. Seperti yang telah diuraikan sebelumnya bahwa teknologi dalam manajeman air sangat dibutuhkan dalam pertanian lahan kering. Teknologi irigasi tetes sudah berkembang secara luas dalam pertanian, namun belum diadopsi oelh petani di NTT. Padahal dengan tipikal pertanian NTT yang memiliki iklim semi-arid (Benu \& Mudita, 2013) yang sangat membutuhkan teknologi ini apabila ingin meningkatkan produktivitas. Namun demikian, mengadopsi sebuah teknologi tentu memiliki konsesuensi tambahan biaya dan juga investasi dalam berusaha tani. Oleh karenaya dibutuhkan suatu kajian tentang pemanfaatan teknologi irigasi tetes dari aspek finansial. Hasil penelitian ini diharapkan dapat memberikan gambaran tentang kelayakan finansial apabila teknologi irigasi tetes ini diaplikasikan dalam agribisnis di lahan kering. 


\section{METODE PENELITIAN}

Penelitian dilakukan di Lahan UPT Laboatorium Lapangan Terpadu/PUI Lahan Kering Kepulauan Universitas Nusa Cendana, pada bulan tahun 2017. Data dihimpun dengan melakukan pencatatanseluruh aktivitas budidaya mulai dari modal investasi, modal kerja, dan juga penerimaan dari prose produksi. Selain itu, dilakukansurveypasar yang ditentukan secara incidental untuk memnuhi kebutuhan data. Data lain yang digunakan bersumber dari BPS Kota Kupang dan Provisnsi NTT.

Data yang telah terkumpul ditabulasi dan dianalisis untuk menjawab permasalahan penelitian. Analisi dilakuakan untuk melihat kelayakan perubahan teknologi dan juga analisis kelayakan dalam jangkan panjang. Analisis pertama akan dilakukan menggunakan analisis parsial dan analisis perubahan teknologi. Sedangkan dalam jangka panjang kelayakan secara ekonomi sebuah investasi teknologi harus dilihat manfaat ekonomi yang ditimbulkannya. Oleh karenaya, dalam penelitian ini dilakukan analisis kelayakan finansial dengan kreteria kelayakan Net Present Value dan Arus benefit dan Biaya (NPV), Internal Rate of Return (IRR) (Kadariah, Karlina, \& Gray, 1999; Swastika, 2004).

Analisis anggaran parsial (Partial Budget Analysis) merupakan analisis finansial yang paling sederhana dalam evaluasi kelayakan suatu teknologi usahatani. Analisis dilakukan untuk menganalisis berapa keutungan dari sebuah proses produksi, sedangkan yang yang kedua dilakukan analisis kelayakan adopsi teknologi baru, yaitu mengganti komponen teknologi. Perubahan komponen teknologi mengakibatkan perubahan struktur biaya dan pendapatan. Pada analisis ini dapat dilihat keuntungan dengan adanya perubahan teknologi yang digunakan (Swastika, 2004). Namum karena teknologi yang dikembangkan membutuhkan invesasi dengan umur ekonomis panjang, maka perlu dilakukan analisis kelayakan investasi. Analisis megnggunakan Net Present Value merupakan selisih antara Present Value dari benefit dengan Present Value dari Biaya yang dihitung dengan rumus seperti disajikan pada Persamaan 1. Selain NPV, maka dihitung juga nilai internal rate of return (IRR). Nilai IRR (Persamaan 2). IRR merupakandiscout rate I yang menyebabkan nilai NPV sama dengan 0 , sehingga dengan melakukan perhitungan IRR, maka diketahui apakah total keuntungan yang diberikan oleh proses produksi dalam perioda tertentu dapat memberikan keutungan diatas suku bunga rata-rata atau sebaliknya (Kadariah et al., 1999).

$$
\begin{aligned}
& N=\sum_{L=1}^{n} \frac{B_{L}-C_{L}}{(1+l)^{L}} \\
& \sum_{L=1}^{n} \frac{B_{L}-C_{L}}{(1+h \quad)^{L}}=O
\end{aligned}
$$

dimana:

$\mathrm{B}_{\mathrm{t}}$ : Benefit kotor

$\mathrm{Ct}$ : Biaya Kotor

$\mathrm{n}$ : Umur ekonomis sebuah proyek 


\section{i ; Social Opportunity Cost of Capital}

Analisis Perubahan teknologi dilakukan untuk melihat dampak pada perubahan struktur biaya dan juga kesempatan berproduksi pada proses produksi tanpa dan dengan teknologi irigasi tetes. Analisis mengacu pada model perhitungan Swastika (2004). Data kondisi penerapan teknologi baru menggunakan data dari hasil pengamatan, pencatatan selama proses produksi, sedangkan budidaya tanpa teknologi (kondisi exsisting) menggunakan data yang sama, namun dengan menghilangkan komponen biaya yang melekat pada teknologi yang diintroduksikan dan memperhitngkan budidaya satu kali tanam dalam satu tahun karena hanya menggunakan pengairan secara alami (hujan).

\section{HASIL DAN PEMBAHASAN}

Penyajian hasil dan Pembahsaan disajikan secara terpisah. Pada bagian awal akan disajikan hasil penelitian baik kelayakan finansial teknologi irigasi tetes dan juga hasil analisis perubahan teknologi. Pada bagian berikutnya dilakukan pembahasan dari hasil penelitian. Adapun hasil dan pembahasan dapat diuraikan sebagai berikut.

\section{Biaya, Produksi dan penerimaan}

Komponen biaya dalam penelitian ini dikelompokkkan menjadi dua, yaitu biaya langsung (biaya Pariabel), dan biaya tidak langsung (Biaya tetap). Biaya langsung adalah biaya yang melekat pada proses produksi, yan meliputi pupuk, tenaga kerja langsung, air, pestisida, dan penyusutan peralatan (Tabel 1). Sedngkan Biaya tidak langsung meliputi biaya sewa lahan, biaya tenaga kerja tetap bidang administrasi, biaya tenaga kerja tetap keamanan, dan juga biaya tenaga kerja penanggung jawab lapangan. Biaya sewa lahan ditetapkan Rp. 200.000,- per are selama satu musim produksi, sedangkan biaya tenaga kerja tetap sesuai dengan tenaga kerja yang di UPT. Pembebanan biaya tenaga kerja tetap ini menggunakan pendekatan biaya tenaga tetap total untuk masing-masing bidang dibagi dengan jumlah petak yang ada pada Tabel 1.

Tabel 1 Biaya Langsung dan Biaya Tetap Masing-Masing Komoditi per Petak tahun 2017

\begin{tabular}{lcrr}
\hline $\begin{array}{c}\text { Komoditas/Jenis } \\
\text { Hortikultura }\end{array}$ & $\begin{array}{c}\text { Luas } \\
\text { petak } \\
\text { (are) }\end{array}$ & $\begin{array}{c}\text { Biaya Total per } \\
\text { Peteak (Rp) }\end{array}$ & $\begin{array}{c}\text { Biaya Tetap } \\
\text { Per Petak (Rp) }\end{array}$ \\
\hline Jagung Bisi 2 (Petak 1) & 3.5 & $1,070,026.18$ & $1,424,137$ \\
Jagung Bisi 2 (Petak 2) & 3.5 & $1,080,585.86$ & $1,424,137$ \\
Jagung Manis (Petak 1) & 3.5 & $1,086,082.22$ & $1,424,137$ \\
Jagung Manis (Petak 2) & 3.5 & $1,193,360.39$ & $1,424,137$ \\
Jagung Manis (Petak 3) & 3.5 & $1,216,000.83$ & $1,424,137$ \\
jagung Manis (Petak 4) & 3.5 & $1,181,168.83$ & $1,424,137$ \\
Baby corn (tanam 1) & 3.5 & $1,108,779.60$ & 712,068 \\
Baby corn (tanam 2) & 3.5 & $989,711.98$ & 712,068 \\
\hline
\end{tabular}




\begin{tabular}{llll}
\hline Tomat & 3.5 & $1,603,204.49$ & $1,424,137$ \\
Semangka & 3.5 & $1,874,809.49$ & $1,424,137$ \\
Ubi Jalar & 2.4 & $1,549,259.87$ & $1,204,137$ \\
\hline
\end{tabular}

Sumber: hasil analisis (2017)

Dari beberapa komoditas yang diteliti, maka masing-masing komoditas memiliki tingkat produktifitas dan harga jual yang beragam. Produktivitas dan harga akan berpengaruh terhadap penerimaan usaha agribisnis. Hasil penelitian menujukkan ubi jalar memberikan penerimaan paling tinggi dibandingkan komoditas lainnya yang dibudidayakan. Sedangkan baby corn memberikan penerimaan paling kecil (Tabel 3). Jagung dengan produk yang dipasarkan berupa jagung manis muda, dan baby corn mempunyai harga jual yang berbeda. Jagung manis dijual per kemasan (4 bulir) dengan harga harga $\mathrm{Rp} 5.000$, sedangkan baby corn dengan harga Rp 25.000 per kg (rata-rata 45 bulir). Tomat dijual dengan sistem borongan deharga Rp. 120.000,tiap keranjang (trey), semangka dijual per buah dengan harga ratarata Rp. 20.000,- per buah, sedangkan ubi jalar dijual Rp. 10.000,- per kilogram (Tabel 2). Berdasarjan harga jual tersebut, maka dihitung penerimaan usaha tani dapt dihitung dengan melihat produksi pada setiap petak tanam. Penerimaan total semua lahan menggunakan asumsi bahwa dari data biaya dan penerimaan yang ada dirata-ratakan, dan dikalikan jumlah petak yang dikelola (Tabel 3).

Tabel 2 Produksi Usahatani Per Jenis Per Are Dalam Satu Musim Tanam di Lahan Kering Undana, tahun 2017

\begin{tabular}{|c|c|c|c|c|c|c|c|}
\hline $\begin{array}{l}\text { Komoditas/Jenis } \\
\text { Hortikultura }\end{array}$ & Satuan & $\begin{array}{l}\text { Luas } \\
\text { petak } \\
\text { (are) }\end{array}$ & $\begin{array}{l}\text { Produksi } \\
\text { Per Petak }\end{array}$ & $\begin{array}{l}\text { Produksi } \\
\text { Per Are }\end{array}$ & $\begin{array}{c}\text { Harga per } \\
\text { satu satuan } \\
\text { Unit (Rp) }\end{array}$ & $\begin{array}{l}\text { Penerimaan } \\
\text { per Petak } \\
\text { (Rp) }\end{array}$ & $\begin{array}{l}\text { Penerimaan } \\
\text { Per Are (Rp) }\end{array}$ \\
\hline $\begin{array}{l}\text { Jagung Bisi } 2 \\
\text { (Petak 1) }\end{array}$ & Bulir & 3.5 & 3500 & 1,000 & 1,250 & $4,375,000$ & $1,250,000$ \\
\hline $\begin{array}{l}\text { Jagung Bisi } 2 \\
\text { (Petak 2) }\end{array}$ & Bulir & 3.5 & 2800 & 800 & 1,250 & $3,500,000$ & $1,000,000$ \\
\hline $\begin{array}{l}\text { Jagung Manis } \\
\text { (Petak 1) }\end{array}$ & Bulir & 3.5 & 3500 & 1,000 & 1,250 & $4,375,000$ & $1,250,000$ \\
\hline $\begin{array}{l}\text { Jagung Manis } \\
\text { (Petak 2) }\end{array}$ & Bulir & 3.5 & 3500 & 1,000 & 1,250 & $4,375,000$ & $1,250,000$ \\
\hline $\begin{array}{l}\text { Jagung Manis } \\
\text { (Petak 3) }\end{array}$ & Bulir & 3.5 & 3500 & 1,000 & 1,250 & $4,375,000$ & $1,250,000$ \\
\hline $\begin{array}{l}\text { jagung Manis } \\
\text { (Petak 4) }\end{array}$ & Bulir & 3.5 & 2800 & 800 & 1,250 & $3,500,000$ & $1,000,000$ \\
\hline $\begin{array}{l}\text { Baby corn } \\
\text { (tanam 1) }\end{array}$ & Bulir & 3.5 & 2800 & 800 & 556 & $1,555,556$ & 444,444 \\
\hline $\begin{array}{l}\text { Baby corn } \\
\text { (tanam 2) }\end{array}$ & Bulir & 3.5 & 2800 & 800 & 556 & $1,555,556$ & 444,444 \\
\hline Tomat & Trey & 3.5 & 38 & 11 & 120,000 & $4,560,000$ & $1,302,857$ \\
\hline Semangka & Buah & 3.5 & 200 & 57 & 20,000 & $4,000,000$ & $1,142,857$ \\
\hline Ubi Jalar & $\mathrm{Kg}$ & 2.4 & 688 & 286.67 & 5,000 & $3,440,000$ & $1,433,333$ \\
\hline
\end{tabular}

Sumber: hasil analisis (2017) 
Tabel 3. Pendapatan Usahatani Berbagai komoditas dalam Satu musim tanam tahun 2017

\begin{tabular}{|c|c|c|c|c|c|c|c|c|c|c|}
\hline \multirow[b]{2}{*}{$\begin{array}{c}\text { Komoditas/Jenis } \\
\text { Hortikultura }\end{array}$} & \multirow[b]{2}{*}{$\begin{array}{l}\text { Luas } \\
\text { petak } \\
\text { (are) }\end{array}$} & \multirow[b]{2}{*}{$\begin{array}{l}\text { Penerimaan } \\
\text { per Petak } \\
\text { (Rp) }\end{array}$} & \multirow{2}{*}{$\begin{array}{l}\text { Biaya } \\
\text { Total } \\
\text { tunai per } \\
\text { Peteak } \\
\text { (Rp) }\end{array}$} & \multirow[b]{2}{*}{$\begin{array}{c}\text { Biaya } \\
\text { tidak } \\
\text { langsung }\end{array}$} & \multirow[b]{2}{*}{$\begin{array}{l}\text { Total } \\
\text { Biaya }\end{array}$} & \multicolumn{2}{|c|}{ Pendapatan } & \multirow[b]{2}{*}{$\begin{array}{l}\mathrm{R} / \mathrm{C} \\
\text { biaya } \\
\text { tunai }\end{array}$} & \multirow[b]{2}{*}{$\begin{array}{c}\mathrm{R} / \mathrm{C} \\
\text { biaya } \\
\text { total }\end{array}$} & \multirow[b]{2}{*}{$\begin{array}{l}\text { B/C } \\
\text { Ratio }\end{array}$} \\
\hline & & & & & & Per Petak & Per Are & & & \\
\hline $\begin{array}{l}\text { Jagung Bisi } 2 \\
\text { (Petak 1) }\end{array}$ & 3.50 & $4,375,000$ & $1,070,026$ & $1,451,034$ & $2,521,060$ & $1,853,940$ & 529,697 & 4 & 1.74 & 0.74 \\
\hline $\begin{array}{l}\text { Jagung Bisi } 2 \\
\text { (Petak 2) }\end{array}$ & 3.50 & $3,500,000$ & $1,080,586$ & $1,451,034$ & $2,531,620$ & 968,380 & 276,680 & 3 & 1.38 & 0.38 \\
\hline $\begin{array}{l}\text { Jagung Manis } \\
\text { (Petak 1) }\end{array}$ & 3.50 & $4,375,000$ & $1,086,082$ & $1,451,034$ & $2,537,116$ & $1,837,884$ & 525,110 & 4 & 1.72 & 0.72 \\
\hline $\begin{array}{l}\text { Jagung Manis } \\
\text { (Petak 2) }\end{array}$ & 3.50 & $4,375,000$ & $1,193,360$ & $1,451,034$ & $2,644,394$ & 1,730,606 & 494,459 & 4 & 1.65 & 0.65 \\
\hline $\begin{array}{l}\text { Jagung Manis } \\
\text { (Petak 3) }\end{array}$ & 3.50 & $4,375,000$ & $1,216,001$ & $1,451,034$ & $2,667,035$ & 1,707,965 & 487,990 & 4 & 1.64 & 0.64 \\
\hline $\begin{array}{l}\text { jagung Manis } \\
\text { (Petak 4) }\end{array}$ & 3.50 & $3,500,000$ & $1,181,169$ & $1,451,034$ & $2,632,203$ & 867,797 & 247,942 & 3 & 1.33 & 0.33 \\
\hline $\begin{array}{l}\text { Baby corn } \\
\text { (tanam } 1)\end{array}$ & 3.50 & $1,555,556$ & $1,108,780$ & $1,451,034$ & $2,559,814$ & $-1,004,258$ & $-286,931$ & 1 & 0.61 & -0.39 \\
\hline $\begin{array}{l}\text { Baby corn } \\
\text { (tanam 2) }\end{array}$ & 3.50 & $1,555,556$ & 989,712 & $1,451,034$ & $2,440,746$ & $-885,191$ & $-252,912$ & 2 & 0.64 & -0.36 \\
\hline Tomat & 3.50 & $4,560,000$ & $1,603,204$ & $1,451,034$ & $3,054,239$ & $1,505,761$ & 430,218 & 3 & 1.49 & 0.49 \\
\hline Semangka & 3.50 & $4,000,000$ & $1,874,809$ & $1,451,034$ & $3,325,844$ & 674,156 & 192,616 & 2 & 1.20 & 0.20 \\
\hline Ubi Jalar & 2.40 & $3,440,000$ & $1,549,260$ & $1,231,034$ & $2,780,294$ & 659,706 & 274,878 & 2 & 1.24 & 0.24 \\
\hline
\end{tabular}

Sumber: hasil analisis (2017)

Dilihat dari $\mathrm{R} / \mathrm{C}$ rasio terhdap biaya tunai, semua komoditas memiliki rasio positif. Namun, apabila dilihat dari R/C rasio terhadap biaya total, maka baby corn tidak mampu memberikan penerimaan minimal sama dengan biaya yang dikeluarkan (Tabel 4). Hal ini menunjukkan bahwa penerimaan hanya mampu mengembalikan $64 \%$ biaya total yang dikeluarkan. Setelah dilakukan pendalaman terhadap produk baby corn, ditemukan adanya penetapan harga jual yang terlalurendah oleh pengelola tempat dilakukannya penelitian dibandingkan dengan harga pasar.

\section{Benefit Cost Ratio (B/C Ratio)} dihitung untuk mendapatkan perbadingan nilai yang diperoleh dari total biaya yang dikeluarkan. Nilai ini menunjukkan seberapa besar nilai manfaat dari setiap rupiah yang dikeluarkan dalam proses produksi. Berdasarkan data yang ada, nilai $\mathrm{BC}$ Ratio positif diperoleh komoditas selain baby corm. Nilai B/C ratio berkisar 0,20 hingga 0,74 . Apabila diratarataakan B/C Ratio termasuk B/C ratio bernilai negatif, maka diperoleh rata-rata sebesar 0,33. Hal ini menunjukkan bahwa setiap Rp. 1.000,- yang dikeluarkan sebagai biaya dalam proses produksi mampu memberikan manfaat sebesar Rp. 331,35 dalam satu musim tanam.

\section{Analisis perubahan teknologi}

Otsuka dan Kodjima (2010) mengatakan teknologi baru akan memberikan kesempatan untuk mendatangkan keuntungan. Oleh karenanya, merujuk metoda analisis yang disampaikan oleh swastika (2004) maka akan dilihat 
apakah teknologi yang diterapkan memberikan nilai manfaat kepada pendapatan usahatani atau tidak. Teknologi irigasi tetes dikembangkan untuk menjawab tantangan keterbatasan produksi karena kendala air. Apabila petani secara tradisional hanya mampu berproduksi satu musim tanam dalam satu tahun, maka dengan teknologi ini, dapat berproduksi sepanjang tahun, dengan catatan bahwa air tetap dapat dipenuhi meskipun secara terbatas dan dialirkan secara efisien. Oleh karenanya, perbandingan manfaat dari adanya teknologi baru akan mengacu pada tambahan biaya atas teknologi yang diterapkan dengan potensi pendapatan yang akan diterima.

Tabel 4. Penerimaan, Biaya, Pendapatan, dan R/C dan B/C Rasio usaha tani dengan metoda konvensional dalam satu musim tanam, tahun 2017

\begin{tabular}{|c|c|c|c|c|c|c|c|c|c|c|}
\hline \multirow{2}{*}{$\begin{array}{l}\text { Komoditas / } \\
\text { Jenis } \\
\text { Hortikultura }\end{array}$} & \multirow{2}{*}{$\begin{array}{l}\text { Luas } \\
\text { petak } \\
\text { (are) }\end{array}$} & \multirow{2}{*}{$\begin{array}{l}\text { Penerimaan } \\
\text { per Petak } \\
(\mathrm{Rp})\end{array}$} & \multirow{2}{*}{$\begin{array}{c}\text { Biaya } \\
\text { Total } \\
\text { tunai per } \\
\text { Petak (Rp) }\end{array}$} & \multirow{2}{*}{$\begin{array}{c}\text { Biaya } \\
\text { tidak } \\
\text { langsung }\end{array}$} & \multirow[b]{2}{*}{$\begin{array}{l}\text { Total } \\
\text { Biaya }\end{array}$} & \multicolumn{2}{|c|}{ Pendapatan } & \multirow{2}{*}{$\begin{array}{c}\mathrm{R} / \mathrm{C} \\
\text { biaya } \\
\text { tunai }\end{array}$} & \multirow{2}{*}{$\begin{array}{l}\mathrm{R} / \mathrm{C} \\
\text { biaya } \\
\text { total }\end{array}$} & \multirow{2}{*}{$\begin{array}{l}\mathrm{B} / \mathrm{C} \\
\text { Ratio }\end{array}$} \\
\hline & & & & & & Per Petak & Per Are & & & \\
\hline $\begin{array}{l}\text { Jagung Bisi } 2 \\
\text { (Petak 1) }\end{array}$ & 3.50 & $4,375,000$ & 413,372 & $1,424,137$ & $1,837,509$ & $2,537,491$ & 724,997 & 11 & 2.38 & 1.38 \\
\hline $\begin{array}{l}\text { () Bisi } 2 \\
\text { 2) }\end{array}$ & 3.50 & $3,500,000$ & 762,139 & $1,424,137$ & $2,186,276$ & $1,313,724$ & 375,350 & 5 & 1.60 & 0.60 \\
\hline $\begin{array}{l}\text { Manis } \\
\text { 1) }\end{array}$ & 3.50 & $4,375,000$ & 794,330 & $1,424,137$ & $2,218,467$ & $2,156,533$ & 616,152 & 6 & 1.97 & 0.97 \\
\hline $\begin{array}{l}\text { 2) Manis } \\
\text { 2) }\end{array}$ & 3.50 & $4,375,000$ & 901,608 & $1,424,137$ & $2,325,745$ & $2,049,255$ & 585,501 & 5 & 1.88 & 0.88 \\
\hline Manis & 3.50 & $4,375,000$ & 924,248 & $1,424,137$ & $2,348,385$ & $2,026,61$ & 579,033 & 5 & 1.86 & 0.86 \\
\hline $\begin{array}{l}\text { jagung Manis } \\
\text { (Petak 4) }\end{array}$ & 3.50 & $3,500,000$ & 924,248 & $1,424,137$ & $2,348,385$ & $1,151,61$ & 329,033 & 4 & 1.49 & 0.49 \\
\hline $\begin{array}{l}\text { Baby corn } \\
(\text { tanam } 1)\end{array}$ & 3.50 & & 899,040 & 537,069 & $1,436,109$ & 119,447 & 34,128 & 2 & 1.08 & 0.08 \\
\hline $\begin{array}{l}\text { Baby corn } \\
\text { (tanam } 2)\end{array}$ & 3.50 & $1,555,556$ & 847,249 & 537,069 & $1,384,317$ & 171,238 & 48,925 & 2 & 1.12 & 0.12 \\
\hline & & & 1,190 & & & & & & & 0.74 \\
\hline & & & 1,462 & & & & & & & 0.39 \\
\hline Ubi Jalar & 2.40 & $3,440,000$ & $1,277,265$ & $1,204,137$ & $2,481,402$ & 958,598 & 399,416 & 3 & 1.39 & 0.39 \\
\hline
\end{tabular}

Sumber: hasil analisis (2017)

\begin{abstract}
Keutungan finansial
perubahan teknologi dengan manggunakan teknologi irigasi tetes dalam satu tahun dapat mencapai $219 \%$ dibandingkan dengan pola awal yang tanpa menggunakan teknologi irigasi tetes. Artinya, teknologi ini memberikan keuntungan dua kali lipat dibadningkan pola produksi tanpa menggunakan teknologi pengairan dalam masa produksi satu tahun. Hal ini dapat terjadi karena adanya kesempatan berproduksi yang lebih
\end{abstract}

banyak karena faktor utama hambatan berproduksi dapat dipenuhi. Perbandingan pendapatan dalam satu musim juga dilakukan dengan membandingkan hasil penelitian ini dengan hasil penelitian pendapatan usahtani di lahan kering. Perbandingan salah komoditas (jagung) hasil penelitian Bahua (2008) pendapatan usaha tani jagung di lahan kering di lokasi penelitiannya sebesar Rp. 2.307.032,61 per ha untuk jagung hibrida, dan Rp. $886.747,70$ per ha 
untuk jagung komposti. Sedangkan pendapatan usahatani yang di lokasi penelitian memberikan pendapatan sebesar Rp. 944,278.24 per are atau berpotensi sebesar Rp. 94.427.824,- per hektar.

Tabel 6. Perbadingan pedapatan usahatani tanpa dan dengan teknologi irigasi tetes dalam satu tahun (2017).

\begin{tabular}{lcc}
\hline $\begin{array}{c}\text { Komoditas/Jenis } \\
\text { Hortikultura }\end{array}$ & $\begin{array}{c}\text { Pendapatan Tanpa } \\
\text { Teknologi Irigasi tetes } \\
\text { (Per Are) }\end{array}$ & $\begin{array}{c}\text { Pendapatan Dengan } \\
\text { teknologi Irigasi Tetes } \\
\text { (Per Are) }\end{array}$ \\
\hline Jagung Bisi 2 (Petak 1) & 724,997 & $1,612,146$ \\
Jagung Bisi 2 (Petak 2) & 375,350 & 853,095 \\
Jagung Manis (Petak 1) & 616,152 & $1,598,384$ \\
Jagung Manis (Petak 2) & 585,501 & $1,506,431$ \\
Jagung Manis (Petak 3) & 579,033 & $1,487,025$ \\
Jagung Manis (Petak 4) & 329,033 & 766,881 \\
Baby Corn (tanam 1) & $-219,321$ & $-454,787$ \\
Baby Corn (tanam 2) & $-204,523$ & $-250,671$ \\
Tomat & 555,799 & $1,313,707$ \\
Semangka & 318,198 & 600,903 \\
Ubi Jalar & 399,416 & 824,633 \\
\hline
\end{tabular}

Sumber: hasil analisis (2017)

\section{Pembahasan}

Teknologi irigasi tetes mampu memberikan manfaat untuk meningkatkan produksi, dan juga mencapai kesempatan perolehan harga yang lebih baik. Seperti yang disampaikan oleh Postel dkk. (2001) bahwa teknologi irigasi tetes memberikan kesempatan dan manfaat kepada petani untuk berproduksi yang lebih baik.Merujuk penelitian Bahua (2008) pendapatan usaha tani jagung di lahan kering di Kecamatan Limboto Kabupaten Gorontalo adalah sebesar Rp. 2.307.032,61 per ha untuk jagung hibrida, dan Rp. $886.747,70$ per ha untuk jagung komposit. Apabila dibandingkan dengan pendapatan usahatani yang dilakukan di lokasi penelitian, maka usahatani jagung dengan menggunakan teknologi irigasi tetes dan dengan penjualan berupa jagung manis memberikan pendapatan sebesar Rp. 944,278.24 per are atau Rp. Berpotensi sebesar
Rp. 94.427.824,- per hektar. Apabila melakukan perbadingan dengan tanpa teknologi tetes dalam satu tahun, perubahan teknologi dengan teknologi irigasi tetes dapat memberikan keutungan finansial mencapai 300\% lebih tinggi dibandingkan dengan keutungan finansial tanpa menggunakan teknologi irigasi tetes. Artinya, teknologi ini memberikan keuntungan tiga kali lipat dibadingkan tanpa menggunakan teknologi pengairan. Hal ini dapat terjadi karena adanya kesempatan berproduksi yang lebih banyak karena faktor utama hambatan berproduksi dapat dipenuhi. Asumsi yang digunakan dalam perbadingan ini adalah keterbatasan curah hujan sebagai faktor pembatas dalam proses produksi hanya mendukung satu musim produksi, sedangkan dengan teknologi irigasi tetes dapat berproduksi sepanjang tahun. Asumsi ini didasarkan oleh 
beberapa faktor seperti curah hujan (Gambar 1), dan juga hasil-hasil penelitian keterbatasan produksi di lahan kering (Beja \& Soetedjo, 2016;
Benu, 2016; Mudita, 2013a, 2013b, 2013c; Yengoh, Armah, Onumah, \& Odoi, 2010).

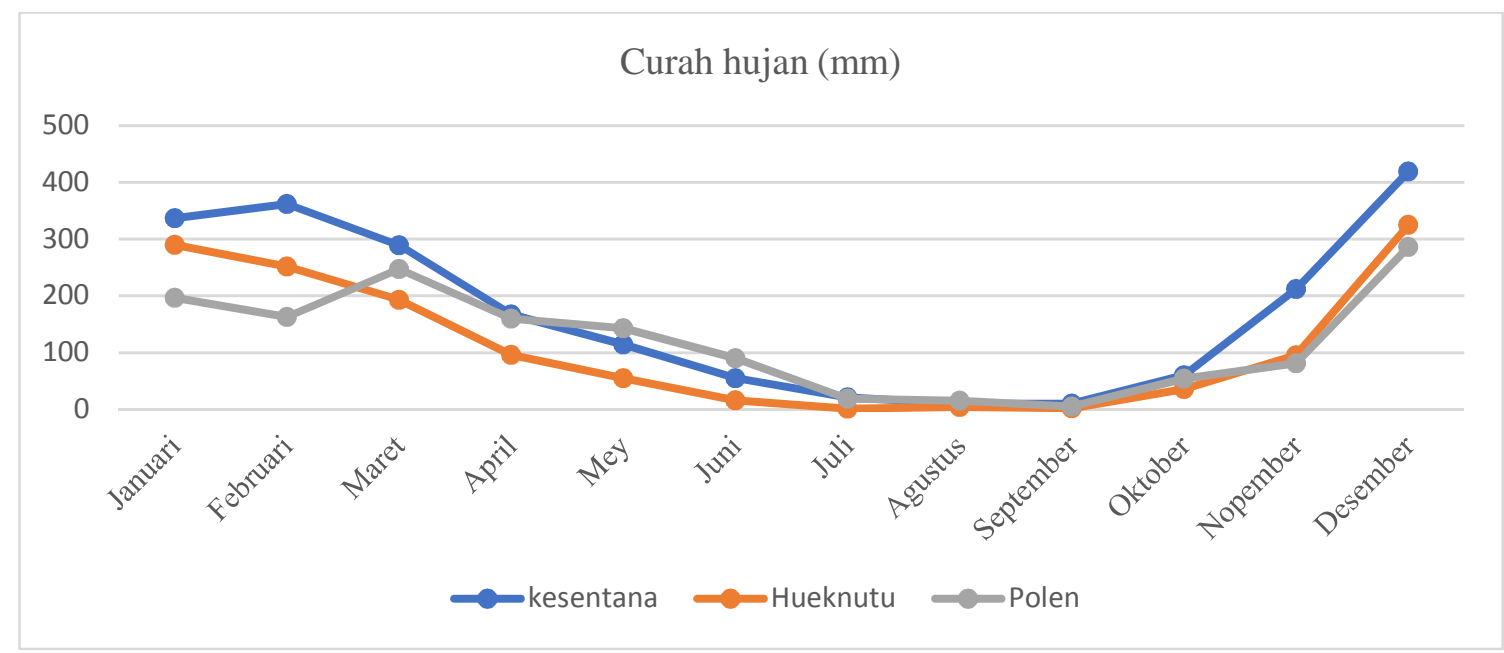

Gambar 1. Data Curah Hujan Sepuluh Tahun Terakhir di Tiga Stasium Pengamatan di Daerah Timor Barat (Nampa et al., 2017)

\begin{tabular}{llr}
\multicolumn{1}{c}{ Dari diskusi } & tersebut \\
menunjukkan bahwa & adopsi \\
teknologi irigasi tetes & dalam \\
agribisnis di lahan & kering \\
memberikan manfaat & secara
\end{tabular}
finansial. Namun demikian, teknologi irigasi tetes ini adalah teknologi pengairan yang memiliki prinsip dasar efisiensi dalam penggunaan air. Artinya air masih tetap harus ada dalam setiap proses budidaya. Dalam penelitian ini, biaya air didekati dengan kebutuhan air dan harga air yang berlaku di Kota Kupang. Dengan manajemen air yang efisien, maka tantangan gagal panen bahkan gagal tumbuh pada pertanian lahan kering seperti yang disampaikan Benu dan Mudita (2013) dapat dikelola dengan baik. Jaminan ketersediaan air ini juga memberikan peluang untuk berproduksi sepanjang musim, sehingga dapat berproduksi pada musim-musim kering (kemarau), sehingga juga berkontribusi terhadap insentif harga pada pemasaran. Meskipun berpotensi memberikan keuntungan yang signifikan, pada penelitian ini baru dilakukan pengukuran pada sekala kecil, sehingga apabila dilakukan perluasan produksi harus memperhitungkan daya serap pasar, agar produksi yang dihasilkan tetap mendapat harga yang kompetitif. Diperlukan pengaturan pola tanam sehingga jagung dapat dirpoduksi secara berkelanjutan. Berdasarkan pengamatan selama penelitian, program penanaman jagung belum dilakukan secara berjenjang, sehingga masih terjadi produksi yang masal dan pada sisi yang lain tidak ada produksi dalam jangka waktu yang panjang. Pengaturan pola tanam dengan menghasilkan produk yang berkesinambungan merupakan dilakukan untuk memecahkan kendala pemasaran 
produk pertanian. Seperti yang disampaikan Syahza (2003) bahwa berbagai masalah dalam pemsaran produk pertanian dalam bidnag produksi adalah tidak adanya kesinambungan dalam produksi, sekala usaha, dan lokasi produksi, dan sifat produk pertanian yang mudah rusak. Pengaturan pola tanam, serta jaminan kesinambungan produksi dengan penerapan teknologi pengairan yang efisien akan menjadi peluang dalam pemasaran.

Secara Finansial, Agribisnis yang diusahakan layak dan mampu memberikan keuntungan pada tingkat suku bunga 12\%. Hal ini menunjukkan bahwa, usaha ini prospektif, dan tetap dapat memberikan keutungan pada inflasi $12 \%$ per tahun. Seperti yang disampaikan oleh Kardarian (1999) bahwa suatu usulan rencana proyek dapat diterima ketika nilai NPV diatas 1 atau NPV positif. Namun demikian, capaian agribisnis di UPT LLTLKK juga dipengaruhi oleh aspek manajemen, sistem manajemen produksi dan pemasaran. Berdasarkan pengamatan selama penelitian, masih ditemukan beberapa kendala dalam manajemen produksi dan operasi agribisnis di UPT LLTLKK. Oleh karenanya, masih harus dilakukan evaluasi dan penyempurnaan. Hasil penelitian menunjukkan belum adanya alur yang jelas (dalam aspek manajemen), khususnya aliran produk dari panen hingga pemasaran. Dengan pemanfaatan lahan sebanyak 58 petak ini, diperlukan manajemen produksi dan juga aliran produk sehingga manajemen dapat melakukan evaluasi secara periodic terhadap produktivitas lahan. Sehingga diperlukan model pengendalian produksi dan aliran produk hingga pemasaran.

\section{KESIMPULAN DAN SARAN}

\section{Kesimpulan}

Berdasarkan hasil dan pembahasan, maka dapat disimpulkan bahwa secara finansial inverstasi teknologi irigasi tetes dalam proses produksi beberapa komoditas yang diteliti tetes layak dan dan menguntungkan. Berdasarkan beberapa indikator kelayakan investasi, agribisnis dengan teknologi irigasi tetes mampu memberikan tingkat keutungan pada suku bunga ratarata $12 \%$ per tahun. Sehingga menginvestasikan modal untuk introduksi teknologi irigasi tetes cukup menguntungkan. Apabila dibadndingkan agribisnis dengan teknologi irigasi tetes dan tanpa teknologi tetes dalam satu tahun, maka perubahan teknologi tersebut dapat memberikan keutungan finansial mencapai 300\%. Selain itu, Irigasi tetes memberikan peluang produksi sepanjang tahun sehingga memiliki keuntungan dalam menjaga kesinambungan dan insentif harga di musim-musim tertentu. Namun demikian, Teknologi irigasi tetes adalah teknologi manajemen air, sehingga ketersediaan air juga tetap harus ada. Sehingga penerapan teknologi ini harus dibarengi dengan ketersediaan sumber air.

\section{Saran}

Berdarkan kesimpulan pada penelitian ini, maka dapat disarankan bahwa teknologi ini masih bergantung pada ketersediaan air, meskipun dengan 
jumlah yang terbatas. Sehingga disaranakan dalam pengembangannya harus memperhitungkan ketersediaan air, selain itu, penelitain ini baru dilakukan dalam jangka waktu satu tahun dengan menggunakn beberapa asumsi, sehingga diperlukan penelitian lebih lanjut pada usahatani yang dilakukan oleh masyarkat dan dengan pencatatan data dengan durasi waktu yang lebih panjang.

\section{DAFTAR PUSTAKA}

Badan Pusat Statistik. (2017). Retrieved September 10, 2017, from https://www.bps.go.id/inde x.php/publikasi/ 14

Bahua, I. (2008). Analisis Usahatani Jagung Pada Lahan Kering Di Kecamatan Limboto Kabupaten Gorontalo. Jurnal Penyuluhan, 4(1). https://doi.org/10.25015/p enyuluhan.v4i1.2168

Beja, H. D., \& Soetedjo, I. P. (2016). Sistem Tebas Bakar dan Pengaruhnya Terhadap Komponen Fisik Kimia Tanah Serta Vegetasi pada Ladang dan Lahan Bera (Studi kasus di Desa Pruda Kecamatan Waiblama Kabupaten Sikka Provinsi Nusa Tenggara Timur). In Strategi Pengembangan Pertanian lahan Kering Berkelanjutan dalam Mengatasi Kerawanan Pangan (pp. 76-89). Kupang: Fakultas Pertanian Universitas Nusa Cendana.

Benu, F. L. (2013a). Bagaimana Cara Mengatasi Keterbatasan Ketersediaan Air dalam
Pertanian Lahan Kering. In Revisitasi Lahan Kering (pp. 33-36). Jakarta: JP II Publishing House.

Benu, F. L. (2013b). Mengapa Disebut Pertanian Lahan Kering, padahal Aktivitas Budidaya PErtanian Selalu Bersentuhan dengan Ketersediaan Air. In Revisitasi Lahan Kering (pp. 13-16). Jakarta: JP II Publishing House.

Benu, F. L. (2016). Strategi Pengelolaan lahan Kering untuk Ketahanan pangan. In Strategi pengembangan pertanian lahan kering Berkelanjutan dalam Mengatasi Kerawanan Pangan (pp. 19-27). Kupang: Fakultas Pertanian Universitas Nusa Cendana.

Benu, F. L., \& Mudita, I. W. (2013). Revisitasi Lahan Kering "Diskusi Ringan Seputra Lahan Kering dan Pertanian Lahan Kering" (Vol. satu). JP II Publishing House.

Kadariah, Karlina, L., \& Gray, C. (1999). Pengantar Evaluasi Proyek (Edisi Revisi) (Edisi Revisi). jakarta: Lembaga Penerbit Fakultas Ekonomi Universitas Indonesia.

M. Likadja, Y., Seran, S., \& Bernandina, L. (2016). Ketersediaan dan konsumsi pangan Pokok Rumah Tangga Petani di Kecamatan Nekamiese Kabupaten Kupang. In Strategi Pengembangan Pertanian lahan kering Berkelanjutan dalam Mengatasi Kerawanan 
Pangan (pp. 297-307). Kupang: Fakultas Pertanian Universitas Nusa Cendana.

Mudita, I. W. (2013a). Apa Itu lahan Kering, Pertanian Lahan Kering, dan Usahatani Lahan Kering. In Revisitasi Lahan Kering (pp. 17-22). Jakarta: JP II Publishing House.

Mudita, I. W. (2013b). Apa Sebenarnya Arti Kering dalam Pertanian Lahan KEring, Usahattani Lahan Kering, dan Bencana Kekeringan. In Revisitasi Lahan Kering (pp. 23-27). Jakarta: JP II Publishing House.

Mudita, I. W. (2013c). Haruskah Petani LahanKering Menanam Jenis-jenis Tanaman yang Diintroduksi dari Luar untuk menjadikan mereka lebih Berorientasi Ekonomis. In Revisitasi Lahan Kering (pp. 41-45). Jakarta: JP II Publishing House.

Nampa, W., Mudita, I. W., Markus, J., L. Natonis, R., \& F. L.B. Riwu Kaho, N. (2017). INNOVATION TO STRENGTHEN HOPES AND DREAMS Learning From Best Practices of an Artisanal Mining Community in Turning Post-Mining Land Rehabilitation Into Agribusiness Opportunities in Tubuhu'e, South Central Timor, East Nusa Tenggara. https://doi.org/10.13140/R G.2.2.17099.28965

Otsuka, K., \& Kijima, Y. (2010). Technology Policies for a
Green Revolution and Agricultural Transformation in Africa. Journal of African Economies, 19(suppl_2), ii60ii76.

https://doi.org/10.1093/jae /ejp025

Postel, S., Polak, P., Gonzales, F., \& Keller, J. (2001). Drip Irrigation for Small Farmers. Water International, 26(1), 313.

https://doi.org/10.1080/02 508060108686882

Swastika, D. K. S. (2004). Beberapa Teknik Analisis Dalam Penelitian Dan Pengkajian Teknologi Pertanian. Jurnal Pengkajian Dan Pengembangan Teknologi Pertanian, Vol. 7(No.1), 90103.

Syahza, A. (2003). PARADIGMA BARU: PEMASARAN PRODUK PERTANIAN BERBASIS AGRIBISNIS DI DAERAH RIAU. Jurnal Ekonomi, Fakultas Ekonomi Universitas Tarumanagara, Jakarta., VIII/(01). Retrieved from

https://s3.amazonaws.com/ academia.edu.documents $/ 28$ 827274 /paradigma_barupe masaran_produk_pertanian_ berbasis_agribisnis_di_daera h_riau.pdf?AWSAccessKeyId $=$ AKIAIWOWYYGZ2Y53UL3A \&Expires $=1515631948 \%$ Sign ature $=\mathrm{dA} 13 \mathrm{WOtcBj} \% 2 \mathrm{BQoZK}$ pEUGiPlFgTuY\%3D\&respons e-contentdisposition=inline $\% 3 \mathrm{~B} \% 20 \mathrm{fil}$ ename\%3DParadigma_Baru_ Pemasaran_Produk_Pertania. pdf 
Yengoh, G. T., Armah, F. A., Onumah, E. E., \& Odoi, J. O. (2010). Trends Agriculturally-Relevant in Rainfall Characteristics for
Small-scale Agriculture in Northern Ghana. Journal of Agricultural Science, 2(3), 3. https://doi.org/10.5539/jas. v2n3p3 